\title{
Arsenate and arsenite removal from contaminated water by iron oxides nanoparticles formed inside a bacterial exopolysaccharide
}

\author{
Barbara Casentini $^{\mathrm{a}, *}$, Michele Gallo ${ }^{\mathrm{b}}$, Franco Baldi ${ }^{\mathrm{b}}$ \\ ${ }^{a}$ Water Research Institute, National Research Council of Italy (IRSA - CNR), Via Salaria, km 29.300, Monterotondo, Rome 00015, Italy \\ ${ }^{\mathrm{b}}$ Department of Molecular Sciences and Nanosystems, Cà Foscari University, Via Torino 155, 30172 Venice, Italy
}

\section{A R T I C L E I N F O}

\section{Keywords:}

\section{Arsenic}

Drinking water

Bioremediation

Exopolysaccharide

Iron nanoparticles

\begin{abstract}
A B S T R A C T
In the last decades, the presence of high As levels in groundwaters poses a serious limitation to the use of this resources for drinking purposes in several parts of the world. Treatment of As-rich waters selected iron oxides filters as more effective, low cost and selective technology. Green and biologically-driven pathways to synthetize new nanostructured iron oxy-hydroxides are becoming always more attractive. We tested the suitability of FeOOH nanoparticles (9-15 nm) produced by Klebsiella oxytoca strain DSM 29614 and encapsulated in EPS gel structure to treat arsenic rich water. Different gel:water volume ratios were tested to treat $5000 \mu \mathrm{g}$ As/L solution. $20 \%$ FeEPS solution was able to remove $95 \%$ of $\mathrm{As}(\mathrm{V})$ while in $5 \%$ solution removal was reduced to $60 \%$. Arsenic adsorption was very fast and follows pseudo- $2^{\text {nd }}$ order kinetic with maximum adsorption capacity reached at about $30 \mathrm{~min}$. Adsorption followed Langmuir model for As(V) with $\mathrm{q}_{\mathrm{max}}=31.8 \mathrm{mg}_{\mathrm{As}} / \mathrm{g}_{\mathrm{Fe}}$ and BET for As(III) with $8 \mathrm{mg}_{\mathrm{As}} / \mathrm{g}_{\mathrm{Fe}}$ for the first layer in $10 \%$ FeEPS solution. FeEPS dried into powder showed noticeable removal only after $2 \mathrm{~h}$, hence not suitable for drinking water treatment. Treatment of natural As levels in mimicked groundwaters showed 87-95\% As(V) and 45-61\% As(III) removal after 5 min. FeEPS gel immobilized onto bivalve shell debris was used in packed-bed filters. It retained $49.8 \mathrm{mg}_{\mathrm{As}} / \mathrm{g}_{\mathrm{Fe}}$ from $150 \mu \mathrm{g} / \mathrm{L} \mathrm{As}(\mathrm{V})$ spiked groundwater before reaching breakthrough at 8000 BVs. Biologically produced FeEPS gel showed good potentialities as eco-friendly material to remove As from contaminated groundwater.
\end{abstract}

\section{Introduction}

Worldwide the presence of elevated natural arsenic concentration in aquifers in groundwater is often limiting its use as drinking water in several parts of the world. In Europe Directive 98/83/EC imposed the limit to $10 \mu \mathrm{g} / \mathrm{L}$ in waters intended for human consumption. Among arsenic removal technologies, adsorption processes gained the upper hand and granular iron hydroxides (GFH) filters are the most widely installed due to GFH natural availability, low cost and easy maintenance. even if its average adsorption capacity is not exceptional and in the range $5-10 \mathrm{mg}_{\mathrm{As}} / \mathrm{g}_{\text {adsorbent }}[1]$.

In the last decades the use of nanoparticles (NPs) in water treatment has been explored. Nano-sized adsorbents showed enhanced reactivity promoted by higher surface area leading to substantial increase in adsorption rates, if compared to granular or powdered adsorption materials. In addition the high efficiency of the nanomaterials reduces filter volume with smaller footprints, suitable for decentralized application and point-of-use-systems [2-4]. In particular nano-metallic oxides, i.e. iron oxy-hydroxides $(\mathrm{FeOOH})$ nanoparticles, have been successfully tested for As removal [3]. Several nanostructured iron oxy-hydroxides (FeNPs) exhibited good As removal efficiency (10-120 $\mathrm{mg}_{\mathrm{As}} / \mathrm{g}_{\text {adsorbent }}$ ) in aqueous systems: akaganeite [ $\beta-\mathrm{FeOOH}]$ [5-7]; $\mathrm{Zr}$-doped akaganeite [8]; maghemite $\left[\gamma-\mathrm{Fe}_{2} \mathrm{O}_{3}\right]$ [9-11]; magnetite $\left[\mathrm{Fe}_{3} \mathrm{O}_{4}\right]$ [12-14]; goethite $[\alpha-\mathrm{FeOOH}][15,16]$; metal oxides heterostructures [17-22]. Chemical syntheses of iron NPs are commonly used, but they are often energy consuming and employ toxic chemicals. There is a growing need to develop reliable and eco-friendly experimental protocols for the synthesis of NPs [23,24]. The biological route is a viable solution, requiring in most of the cases ambient temperature, low pressure, neutral $\mathrm{pH}$ and generating uniform NPs with size ranging from 5 to $100 \mathrm{~nm}$ [25]. Saif et al. (2016) listed various green agents usable for the synthesis of iron NPs such as polymers, amino acids, bacteria, fungi, plant extracts, etc., and drafted their reaction pathways. Since 90 's, it was reported that dissimilatory Fe(III)-reducing microorganisms can couple the oxidation of organic materials to the reduction of $\mathrm{Fe}(\mathrm{III})$, giving as end-product ultrafine-grained magnetite [26]. Other bacteria were able to synthetize magnetite: Desulfovibrio magneticus strain $\mathrm{RS}^{-1}$, Thermoanaerobacter ethanolicus, Magnetospirillum magnetotacticum,

\footnotetext{
* Corresponding author.

E-mail address: casentini@irsa.cnr.it (B. Casentini).
} 
Shewanella putrefaciens strain $\mathrm{GS}^{-1} 5$ [23]. Bacterial fermentation represents a fundamental new approach for large-scale production of nanometer-sized crystalline particles. [27] reported that under anaerobic laboratory conditions, Klebsiella oxytoca strain DSM 29,614 (ex $\mathrm{BAS}^{-1} 0$ ) fermented $\mathrm{Fe}(\mathrm{III})$-citrate and Na-citrate giving $\mathrm{CH}_{3} \mathrm{COOH}$ and $\mathrm{CO}_{2}$ with a simultaneous production of a considerable amount of ferric hydrogel, composed by branched heptasaccharide repeating units exopolysaccharide (EPS) with metal content up to $36 \mathrm{wt} \%[28,29]$. The production of FeEPS under anaerobic conditions is a strategy adopted by the strain to survive in extreme conditions such as acid mine drainages with high heavy metal concentrations. This strategy could be efficiently used to produce large amount of valuable FeEPS, starting from a low cost substrate as Fe(III) citrate. Furthermore, FeNPs encapsulated in EPS have the advantage that gel structure functions as capping agent preventing clustering and flocculation of NPs.

It is known that negative charges/complexing molecules present in the EPS are able to interact with potentially toxic metals $(\mathrm{Cd}, \mathrm{Cu}, \mathrm{Pb}$, $\mathrm{Ni}, \mathrm{Hg} . .$.$) positively charged. Removal process follows several possible$ pathways [30]: the creation of electrostatic bonds among metals and negatively charged groups (i.e. carboxylic and phosphoric groups), ion exchange with protons present on the surface and the formation of a metal-ligand coordination bond [31]. In most cases, the ionic nature of metal, its size and charge density in turn regulates its interaction with negatively charged EPS [30]. On the contrary, literature on the removal of negatively charged oxyanions (i.e. arsenate, chromate, selenite, vanadate ...) is rare. The presence of iron oxy-hydroxides NPs in EPS may extend the bioremediation use of this material to anionic classes of contaminants.

The application of FeEPS to sequester arsenic species sounds very promising. Therefore, we tested the potentialities of green FeOOH-EPS to treat As-rich drinking water. FeEPS NPs were tested in the form of hydrogel and dehydrated powder to evaluate best performance for a successful drinking water treatment. Different aspects were elucidated, i.e. the form of the biosorbent more effective (hydrogel vs powder), kinetic aspects of the removal process and related adsorption isotherms at different concentrations of $\mathrm{As}(\mathrm{III}), \mathrm{As}(\mathrm{V})$ and matrices. Adsorption processes were evaluated through batch studies by the application of kinetic and isotherm adsorption models. A preliminary column (packed bed) study was also carried out to test efficiency to remove As of FeEPS adsorbed onto a solid support.

\section{Experimental}

\subsection{Reagents}

All chemicals and reagents were of analytical grade. Arsenic (V) and (III) stock solutions ( $1000 \mathrm{mg} / \mathrm{L}$ ) were prepared using $\mathrm{Na}_{2} \mathrm{HAsO}_{4} * 7 \mathrm{H}_{2} \mathrm{O}$ (Fluka) and $\mathrm{Na}_{2} \mathrm{AsO}_{2}$ (Fluka), respectively. Iron (III) and (II) stock solutions $(1000 \mathrm{mg} / \mathrm{L})$ were prepared from $\mathrm{Fe}\left(\mathrm{NO}_{3}\right)_{3} * 9 \mathrm{H} 2 \mathrm{O}$ (Merck) and $\mathrm{FeSO}_{4} * 7 \mathrm{H}_{2} \mathrm{O}$ (Sigma Aldrich), respectively. $\mathrm{HNO}_{3}$ (Merck, Suprapur), $\mathrm{HCl}$ (Merck, Suprapur), sodium acetate (Riedel-Hahn), acetic acid (Carlo Erba), Ortho-phenantroline (Sigma Aldrich), hydroxylamine (Sigma Aldrich) were used for the FeEPS digestion and Fe detection.

\subsection{Production of biogenerated FeEPS}

Iron NPs hydrogel (FeEPS) was synthetized by Klebsiella oxytoca strain DSM 29,614 isolated from acid mine drainage. Details Fe(III) citrate fermentation process and EPS structure could be found elsewhere [28]. At stationary phase, the strain produces a ferric exopolymeric hydrogel with entrapped Fe NPs [32], similar to ferric hydroxides in ferritin [33]. FeEPS was extracted by the bacterial culture and precipitated using $70 \%$ ethanol solution at $4{ }^{\circ} \mathrm{C}$. In our experiments alcoholic fraction was removed by washing with MilliQ water. Fe NPs embedded in the EPS gel were 9-15 nm [32,33] with +2.82 average $\mathrm{Fe}$ valence [33]. FeEPS powder was produced by drying the gel in oven at $30^{\circ} \mathrm{C}$. After acid digestion (Section 2.3), measured Fe content of FeEPS gel and powder was $2.5 \pm 0.2 \mathrm{mg}_{\mathrm{Fe}} / \mathrm{ml}$ and $0.3 \pm 0.1 \mathrm{mg}_{\mathrm{Fe}} / \mathrm{mg}_{\text {powd }}$, respectively.

\subsection{Analytical methods}

Temperature, $\mathrm{pH}$ and conductivity (EC) were in situ measured by probes (Hach HQ 30 d). Total arsenic was measured by Atomic Absorption Spectrometry (Perkin Elmer AAnalyst 800) equipped with Ir-coated THGA furnace. Spectrophotometric Fe determination required hydroxylamine pre-reduction and $O$-phenantroline complexation with present $\mathrm{Fe}^{+2}$ at acetate buffered conditions $(\mathrm{pH}=4.5)$. Red complexes were read at $512 \mathrm{~nm}$ [34]. Fe content in stock Fe-EPS gel and Fe-EPS powder was measured by digesting $20 \mathrm{ml}$ of Fe-EPS with $2 \mathrm{ml} \mathrm{HNO}_{3}$ or $50 \mathrm{mg}$ Fe-EPS powder with $4.5 \mathrm{ml} \mathrm{HCl}+2 \mathrm{ml} \mathrm{HNO}_{3}$. Total Fe solubilisation was achieved by heating at $40{ }^{\circ} \mathrm{C}$ for $30 \mathrm{~min}$ and $\mathrm{Fe}$ spectrophotometrically quantified after dilution. Z-potential measurements were carried out using $1 \mathrm{ml} \mathrm{10 \%} \mathrm{FeEPS} \mathrm{solution} \mathrm{in} \mathrm{the} \mathrm{pH}$ range 2.5-7 by Zetasizer Nano (Lavern Instruments). Point of zero charge $\left(\mathrm{pH}_{\mathrm{pzc}}\right)$ was calculated from the plot (Annex A1).

\subsection{Experimental setup}

Batch and column studies were carried out in MilliQ water at controlled $\mathrm{pH}$ and on real matrices using two different groundwaters of Medium conductivity (M_EC, $500 \mu \mathrm{S} / \mathrm{cm}$ ) and High conductivity (H_EC, $1000 \mu \mathrm{S} / \mathrm{cm}$ ), rich in sulphate and carbonate (Annex A2).

\subsubsection{Adsorption kinetic batch tests}

A preliminary kinetic test was run to evaluate potential As removal by different FeEPS ratio (v:v) and Fe concentration in solution after $5 \mathrm{~min} 9000 \mathrm{rpm}(10,414 \mathrm{rcf})$ centrifugation and/or $0.2 \mu \mathrm{m}$ filtration (acetate cellulose). FeEPS gel solutions were prepared by adding $2 \mathrm{ml}$ FeEPS stock solution to different MilliQ volumes in the range 1:1 up to 1:250 (ml $\mathrm{meEPS}_{\mathrm{FeES}}: \mathrm{ml}_{\text {water }}$ ). Solutions were spiked $1000 \mu \mathrm{g} / \mathrm{L} \mathrm{As}(\mathrm{V})$ and analysed after $10 \mathrm{~min}$ to calculate As removal. Preliminary test evidenced the good potential of FeEPS gel to fast remove As but excessive concentration of Fe in surnatant solution was found after centrifugation and $0.2 \mu \mathrm{m}$ sample filtration was then always required. Arsenic removal after 10 min ranged from 4.8 to $94.3 \%$ (Annex A3). Considering to avoid high density of the Fe rich gel (not suitable for drinking water) and the removal efficiency, 1:5 (20\% FeEPS, Gel 1) and 1:20 (5\% FeEPS, Gel 2) dilutions were chosen to run first kinetic tests. 1:10 (10\% FeEPS) was chosen to perform further kinetic, adsorption, desorption and column tests. Arsenic removal by Gel 1 and 2 was studied in $250 \mathrm{ml}$ batches spiked $5000 \mu \mathrm{g} / \mathrm{L} \mathrm{As}(\mathrm{V})$ at $\mathrm{pH} 7 \pm 0.5$ and sampled at selected time intervals $(1 ; 5 ; 10 ; 30 ; 60 ; 120$ and $360 \mathrm{~min})$. During a second test, the performances of gel and powder FeEPS were compared in $50 \mathrm{ml}$ solution at pH $7 \pm 0.5$ with lower As initial concentration $[2000 \mu \mathrm{g} / \mathrm{L}$ $\mathrm{As}(\mathrm{V})]$. Fe gel and powder solutions were prepared at two different dilutions: 20\% (Gel 3, Powder 1) and 5\% (Gel 4, Powder 2) by keeping similar Fe amount between powder and gel. Solutions were sampled at $0.2,0.5,1,2,3.5,6$ and $24 \mathrm{~h}$. A summary of all kinetic tests conditions is given in Table 1 .

In MilliQ and real matrices (M_EC and H_EC) similar to As-rich groundwaters exploited for human consumption in Italy at an $150 \mu \mathrm{g} / \mathrm{L}$ initial $\mathrm{As}(\mathrm{V})$ or $\mathrm{As}(\mathrm{III})$, arsenic removal efficiency was tested using $10 \%$ FeEPS ( $5 \mathrm{ml}$ in $50 \mathrm{ml}, 11.3 \mathrm{mg}$ Fe) in fast kinetic study ( $35 \mathrm{~min}$ ) [35,36]. Samples were collected at 5, 10, 20 and $35 \mathrm{~min}$. To evaluate the adsorption properties of $10 \%$ FeEPS gel under consecutive As exposures, batch adsorption was repeated by discarding surnatant and adding again new $50 \mathrm{ml}$ As solution at $150 \mu / \mathrm{L}$ As-rich water to same FeEPS gel. After the third consecutive adsorption, $50 \mathrm{ml}$ MilliQ water were added to centrifuged FeEPS in order to test possible desorption processes of trapped As from FeEPS. Samples were taken after $16 \mathrm{~h}$ and 3 days. 
Table 1

Summary of kinetic tests carried out using different hydrogel solutions and dried FeEPS powder.

\begin{tabular}{|c|c|c|c|c|c|c|}
\hline & Gel 1 & Gel 2 & Gel 3 & Gel 4 & Powder 1 & Powder 2 \\
\hline $\begin{array}{c}\text { Fe amount } \\
(\mathrm{mg})\end{array}$ & 135 & 34 & 24.2 & 6 & 25.6 & 6.4 \\
\hline $\begin{array}{c}{[\mathrm{Fe}]} \\
(\mathrm{mg} \mathrm{Fe} / \mathrm{L})\end{array}$ & 540 & 108 & 484 & 120 & 512 & 128 \\
\hline $\begin{array}{c}\text { Volume } \\
(m L)\end{array}$ & 250 & 250 & 50 & 50 & 50 & 50 \\
\hline$\%$ FeEPS & $20 \%$ & $5 \%$ & $20 \%$ & $5 \%$ & $\begin{array}{c}\text { Equivalent } \\
\text { to } 20 \%\end{array}$ & $\begin{array}{c}\text { Equivalent } \\
\text { to } 5 \%\end{array}$ \\
\hline $\begin{array}{l}\text { time } \\
\text { (min) }\end{array}$ & \multicolumn{6}{|c|}{ As Removal (\%) } \\
\hline 10 & $86 \%$ & $44 \%$ & $23 \%$ & $5 \%$ & $0 \%$ & $0 \%$ \\
\hline 360 & $95 \%$ & $59 \%$ & $27 \%$ & $20 \%$ & $33 \%$ & $21 \%$ \\
\hline 1440 & & & $35 \%$ & $33 \%$ & $59 \%$ & $44 \%$ \\
\hline $\begin{array}{c}{[\mathbf{A s V}]_{0}} \\
\left(\mu g_{A s} / L\right)\end{array}$ & 5000 & 5000 & 2000 & 2000 & 2000 & 2000 \\
\hline $\begin{array}{c}\text { Initial As:Fe } \\
\left(m g_{A s} / g_{F e}\right)\end{array}$ & 9.3 & 36.8 & 4.1 & 16.7 & 3.9 & 15.6 \\
\hline $\begin{array}{c}\mathbf{q}_{360} \\
\left(m g_{A s} / g_{F e}\right)\end{array}$ & 8.8 & 21.5 & 1.1 & 3.4 & 1.3 & 3.3 \\
\hline
\end{tabular}

\subsubsection{Adsorption batch isotherms}

Maximum adsorption capacity ( $\mathrm{q}_{\max }$ ) was calculated for both As(III) and $\mathrm{As}(\mathrm{V})$ in $10 \%$ FeEPS (4.8 mg Fe in $20 \mathrm{ml}, 240 \mathrm{mg}_{\mathrm{Fe}} / \mathrm{L}$ ) and $20 \%$ FeEPS powder $\left(10.4 \mathrm{mg}_{\mathrm{Fe}}\right.$ in $\left.20 \mathrm{ml}, 520 \mathrm{mg}_{\mathrm{Fe}} / \mathrm{L}\right)$ in batch studies. Initial As concentration ranged from 0.25 to $20 \mathrm{mg} / \mathrm{L}$ and $\mathrm{pH}$ was $7 \pm 0.5$. Samples were collected after $20 \mathrm{~h}$.

\subsubsection{Column study}

Small column ( $\varnothing 1 \mathrm{~cm}, \mathrm{H} 8 \mathrm{~cm}$ ) fed by H_EC water at $10 \mathrm{ml} / \mathrm{min}$ was initially prepared using FeEPS hydrogel, but after few minutes clogging occurred. A new material was then prepared by dispersing FeEPS hydrogel onto crushed carbonaceous natural material (FeEPS solid). The latter is constituted by beached shells of Cardium spp, with a specific grain-size $(1-3 \mathrm{~mm})$ and low specific surface area of about $3 \mathrm{~m}^{2} / \mathrm{g}$. The total Fe content of this new mixed material was $0.01 \mathrm{mg}_{\mathrm{Fe}} / \mathrm{mg}_{\text {adsorbent }}$. Small column was filled with $4 \mathrm{~g}$ FeEPS solid $(\mathrm{H} 4 \mathrm{~cm}$, Bed Volume $3.1 \mathrm{ml})$. Column was fed by H_EC spiked groundwater at $200 \mu \mathrm{g} \mathrm{As}(\mathrm{V}) / \mathrm{L}$ and flow set to $10 \mathrm{ml} / \mathrm{min}(0.6 \mathrm{~L} / \mathrm{h}$, linear velocity $7.6 \mathrm{~m} / \mathrm{h}$, EBCT $18.8 \mathrm{~s})$.

\subsection{Adsorption models}

Several kinetics and thermodynamics models to describe arsenic adsorption processes have been previously reported [37-41].

\subsubsection{Kinetic models}

The use of kinetic equations helps to better identify mechanisms of adsorption, identification of rate-determining steps and predict the adsorption rate. Generally, liquid/solid adsorption involves three main processes: film diffusion, intraparticle diffusion and mass action. In physical adsorption, mass action is very fast, therefore the rate limiting steps usually correspond with the other two processes [42].

2.5.1.1. Pseudo $1^{\text {st }}$ and $2^{\text {nd }}$ order kinetic models. Data obtained by batch experiments were analysed by employing linearized pseudo-first order (1) and pseudo-second order (2) equations:

$q_{t}=q_{1}\left[1-e^{-k_{1} t}\right]$ pseudo 1st order

$q_{t}=q_{2} \frac{k_{2} q_{2} t}{1+k_{2} q_{2} t}$ pseudo 2nd order

where $q_{t}$ is the amount of As adsorbed $(\mathrm{mg} / \mathrm{g})$ at time $t, q_{1}$ is pseudo $1^{\text {st }}$ order maximum adsorption capacity $(\mathrm{mg} / \mathrm{g})$ and $q_{2}$ for the pseudo $2^{\text {nd }}$ order equation, $k_{1}$ is the pseudo-first order rate constant $\left(\mathrm{min}^{-1}\right)$ and $k_{2}$ is the pseudo-second order rate constant $(\mathrm{g} / \mathrm{mg} \mathrm{min})$ [43]. Usually the pseudo-first order equation apply to reversible adsorption reactions while the pseudo-second order kinetic model consider chemical adsorption as the rate determining step. Parameters were calculated using SOLVER tool in Excel by minimizing Sum of Squares according to the abovementioned kinetic equations in non-linearized form.

2.5.1.2. Weber-Morris. In order to test if intraparticle diffusion, usually the rate-limiting step in arsenic adsorption, was involved and limiting the adsorption process, Weber and Morris (1963) diffusion model was applied to our data:

$q_{t}=k_{\text {int }} t^{1 / 2}+C_{i}$

where $\mathrm{q}_{\mathrm{t}}(\mathrm{mg} / \mathrm{g})$ is the amount of As adsorbed at time $\mathrm{t}$ at equilibrium,

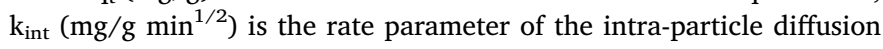
control stage and $C_{i}(\mathrm{mg} / \mathrm{g})$ indicates the thickness of the boundary layer. This model suggests that if adsorption mechanism is via intraparticle diffusion then the plot will be linear when is the sole rate-limiting step it will pass through the origin [41,42]. When the sorption process is controlled by more than one mechanism, then the plot will be multilinear and a multistage processes could be identified $[41,44]$.

\subsubsection{Adsorption isotherm models}

Among the several available models usually used to fit adsorption experiments, we selected Langmuir, Freundlich and BET isotherm models [45].

2.5.2.1. Langmuir isotherm. This model describes solute-adsorbent equilibrium by assuming a monolayer coverage with all sites energetically equally probable [46]. It follows the equation:

$q_{e}=\frac{\mathrm{q}_{\max } \mathrm{bC}_{\mathrm{e}}}{1+\mathrm{bC}_{\mathrm{e}}}$

where $q_{e}$ is the measured equilibrium adsorption capacity $\left(\mathrm{mg}_{\mathrm{As}} / \mathrm{g}_{\mathrm{Fe}}\right)$, $C_{e}$ is the measured equilibrium solute concentration $(\mathrm{mg} / \mathrm{L}), q_{\max }$ is the maximum adsorption capacity of a monolayer stratum $\left(\mathrm{mg}_{\mathrm{As}} / \mathrm{g}_{\mathrm{Fe}}\right)$ and $b$ is the coefficient of Langmuir bond energy $(\mathrm{L} / \mathrm{mg}$ ) given by adsorption/ desorption constants ratio. 
2.5.2.2. Freundlich isotherm. This empirical model considers adsorption sites at different energies with stronger binding sites firstly occupied [46]. It follows the equation:

$q_{e}=K_{f} C_{e}^{1 / n}$

where $q_{e}$ is the measured equilibrium adsorption capacity $\left(\mathrm{mg}_{\mathrm{As}} / \mathrm{g}_{\mathrm{Fe}}\right)$, $C_{e}$ is the measured equilibrium solute concentration $(\mathrm{mg} / \mathrm{L}), K_{f}$ is an indicator of the adsorption capacity $(\mathrm{L} / \mathrm{mg}$ ) increasing simultaneously with the increase of maximum adsorption capacity and $1 / n$ is an indicator of adsorption intensity.

2.5.2.3. BET isotherm. Originally developed to describe gas/solid adsorption, its application has been extended also to describe multilayers adsorption processes. BET isotherm represents an extension of Langmuir model, and it hypothesizes that further adsorption is possible on the first adsorption layer even when first strata adsorption sites coverage is not completed yet [47]. It follows the equation:

$q_{e}=\frac{K_{b} C_{e} q_{\max }}{\left(C_{s}-C_{e}\right)\left[1+\left(K_{b}-1\right) \frac{C_{e}}{C_{s}}\right]}$

where $q_{e}$ is the measured equilibrium adsorption capacity $\left(\mathrm{mg}_{\mathrm{As}} / \mathrm{g}_{\mathrm{Fe}}\right)$, $C_{e}$ is the measured equilibrium solute concentration $(\mathrm{mg} / \mathrm{L}), C_{S}$ is solute concentration saturating first layer $(\mathrm{mg} / \mathrm{L}), q_{\max }$ is the maximum adsorption capacity of a monolayer stratum $\left(\mathrm{mg}_{\mathrm{As}} / \mathrm{g}_{\mathrm{Fe}}\right)$ corresponding to Langmuir model. If $\mathrm{C}_{\mathrm{s}}>>\mathrm{C}_{\mathrm{e}}$ and $\mathrm{K}_{\mathrm{b}}>>1$, BET isotherm follows Langmuir. Due the difficulties in value parameters determination, it has been suggested to suppose at a first stage a plausible value for $C_{S}$ and iteratively calculate all the parameters to approach $R^{2}$ as close as possible to 1 .

\subsubsection{Models evaluation}

The goodness of fit was then evaluated by calculating the coefficient of determination $\left(\mathrm{R}^{2}\right)$ and the Root Mean Square Error (RMSE), where $\mathrm{R}^{2}$ represents the relative measure of fit (trend prediction), while RMSE is an absolute measure of fit (model accuracy).

Coefficient of Determination $\mathbf{R}^{2}=\frac{\sum\left(\mathbf{x}_{\mathbf{m}}-\overline{\mathbf{x}_{\mathbf{e}}}\right)^{2}}{\sum\left(\mathbf{x}_{\mathbf{m}}-\overline{\mathbf{x}_{\mathbf{e}}}\right)^{2}+\sum\left(\mathbf{x}_{\mathbf{m}}-\mathbf{x}_{\mathbf{e}}\right)^{2}}$

Root Mean Square Error RMSE $=\sqrt{\frac{1}{n} \sum_{i=1}^{i=n}\left(x_{m}-x_{e}\right)^{2}}$

where $x_{m}$ is the value given by the model, $x_{e}$ is the experimental data and $\overline{x_{\mathrm{e}}}$ is the mean value of experimental dataset [48].

\section{Results and Discussion}

\subsection{Kinetic behaviour of FeEPS}

Arsenate adsorption at initial concentration of $5000 \mu \mathrm{g} / \mathrm{L}$ was $95.1 \%$ and $58.6 \%$ for 20\% FeEPS (135 mg Fe) and 5\% FeEPS (34 mg Fe), respectively (Fig. 1). Within first $30 \mathrm{~min}$ was already $90.1 \%$ for $20 \%$ FeEPS and $41.8 \%$ for $5 \%$ FeEPS.

Even if 5\% FeEPS solution was less effective in terms of total removal, its final adsorption capacity was higher, being $21.5 \mathrm{mg}_{\mathrm{As}} / \mathrm{g}_{\mathrm{Fe}}$ instead of $8.8 \mathrm{mg}_{\mathrm{As}} / \mathrm{g}_{\mathrm{Fe}}$ at higher FeEPS concentration. FeEPS gel showed $\mathrm{pH}_{\mathrm{pzc}}$ of 3.2 (Annex A1), hence at working $\mathrm{pH}$ of 7 exhibits a negative surface charge not favouring oxyanions adsorption. Usually $\mathrm{pH}_{\mathrm{pzc}}$ for $\mathrm{FeOOH}$ mineral phases is around 6.5-9.5 [49] and at natural $\mathrm{pH}$ their positive charge is promoting adsorption of negatively charged arsenate. By applying kinetic models (Section 2.5.1), we concluded that adsorption follows pseudo- $2^{\text {nd }}$ order kinetic for both FeEPS dilutions with $\mathrm{R}^{2}=0.75$ and RMSE $=0.43$ for $20 \%$ FeEPS and $\mathrm{R}^{2}=0.59$ and RMSE $=2.67$ for $5 \%$ FeEPS (See Annex A4). Higher adsorption in concentrated gel could be explained by higher amount of adsorption sites in solution, but at this gel concentration, repulsion forces could also reduce specific adsorption. In this case the limiting step should be represented by the penetration of the so-called "boundary layer". Weber-Morris intraparticle diffusion model was applied (Fig. 1) in order to elucidate which processes were involved during As adsorption in FeEPS hydrogel and their influence on the overall adsorption. WeberMorris plot evidenced as in both cases the straight line did not pass through zero hence the presence of a boundary layer, but no multistage process is observed and the only limiting-rate process was intraparticle diffusion, before reaching an equilibrium plateau. The thickness of boundary layer given by the intercept correspond to 6.5 and $11.1 \mathrm{mg} / \mathrm{g}$ for $20 \%$ and $5 \%$ FeEPS. Contrary to what observed by other authors $[39,41]$, the lack of an initial stage related to film diffusion suggested that boundary layer was not limiting in our case. We finally hypothesize that at the same time EPS may exert repulsion with As ions but also facilitate the entrapment into the gel by EPS polysaccharides driven chelation and speeding up the adsorption process, as evidenced by higher adsorption rate during first minutes, in line with what evidenced for positively charged potentially toxic metals [30]. The high chelation efficiency of EPS has recently been confirmed for $\mathrm{Hg}^{2+}$ [50].

Due to the difficulties that may occur while managing gel formulation in drinking water treatment, kinetic tests were also carried out on dried FeEPS powder. Hydrogel vs powder, containing similar $\mathrm{Fe}$ concentrations (mg/L), were tested at initial $2000 \mu \mathrm{g} / \mathrm{L} \mathrm{As}(\mathrm{V})$ for $24 \mathrm{~h}$ at two adsorbent:solution ratios (see Table 1 for details). FeEPS powder adsorption showed slow removal increasing only after $2 \mathrm{~h}$ up to $24 \mathrm{~h}$ (Fig. 2), most probably caused by reduced penetrability of this dried material and less accessibility for As to adsorption sites. In hydrogel As desorption was observed after $2 \mathrm{~h}$ and after one day removal stabilized to a value around 35\% for both Gel 3 and Gel 4. On a long-term basis, powder formulation may be also effective, since removal reached $59 \%$ in Powder 1 and 44\% in Powder 2.

Even during these experiments, despite the lower content of Fe $(\approx$ $35 \mathrm{mg}$ at $20 \%$ FeEPS and $6 \mathrm{mg}$ at 5\% FeEPS), diluted solutions showed highest adsorption capacity: 3.4 versus $1.1 \mathrm{mg}_{\mathrm{As}} / \mathrm{g}_{\mathrm{Fe}}$ in gel and 3.3 versus 1.1 for powder. Lower adsorption capacity, if compared first kinetic results, were due to lower initial As:Fe ratio (see Table 1).

At last fast kinetic experiment was carried out in different real water matrices at varying ionic contents (see Section 2.4.1 and Annex A2) and natural occurring groundwater concentration for both species As(V) and As(III). After $10 \mathrm{~min}$ in real groundwaters, FeEPS formed naked-eye visible clusters and coagulated due to salting-out effect. Arsenate removal was $87-95 \%$ after only $5 \mathrm{~min}$ and increased a little further up to 30 min (Fig. 3). Best removal capacity was observed in M_EC groundwater (up to $97 \%$ ) with As concentration always below drinking water limit (10 $\mu \mathrm{g} / \mathrm{L}$, European Directive 98/83/EC). Arsenite removal was initially fast as well but less performing with 45-61\% As(III) removed after $5 \mathrm{~min}$ and a significant increase after $30 \mathrm{~min}$. Best final removal (74\%) was again obtained in M_EC water, followed by MilliQ (69\%) and H_EC water $(62 \%)$.

In line with what observed by [51], the presence of sulfate did not influence much arsenate adsorption but resulted in a considerable reduction in arsenite adsorption. At circumneutral $\mathrm{pH}$, better $\mathrm{As}(\mathrm{V})$ adsorption respect to uncharged As(III) is due to its negative charge that can quickly react with $-\mathrm{OH}_{2}{ }^{+}$group onto $\mathrm{Fe}$ oxy-hydroxides surface [52]. Best efficiency of M-EC water, could be attributed to a better buffer capacity to $\mathrm{pH}$ 7-7.5 than MQ, which limited the natural $\mathrm{pH}$ increase following arsenate adsorption. While on the other side higher ionic strength water $(\mathrm{H}-\mathrm{EC})$ reduced $\mathrm{As}(\mathrm{V})$ ions mobility towards charged adsorption sites. Furthermore, [53] carried out a specific study of arsenate adsorption onto hematite and highlighted the possible influence of carbonate on enhancing $A s(V)$ uptake. Effect of dissolved carbonate on $\mathrm{As}(\mathrm{V})$ adsorption depends on several conditions [e.g., surface available sites, initial $\mathrm{As}(\mathrm{V})$ and reaction times] and under certain conditions carbonate become competing ion to $\mathrm{As}(\mathrm{V})$. 


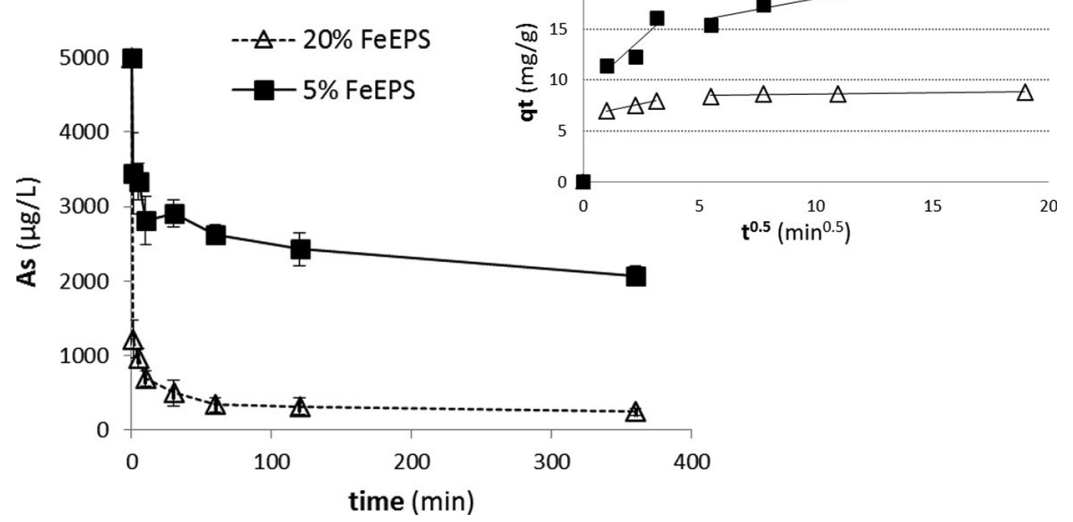

Fig. 1. Arsenate adsorption kinetic at different gel dilution ( $5 \%$ and $20 \% \mathrm{FeEPS})$ and $\mathrm{As}(\mathrm{V})=5000 \mu \mathrm{g} / \mathrm{L}$. Related intraparticle diffusion model (Weber-Morris) trends are also reported.

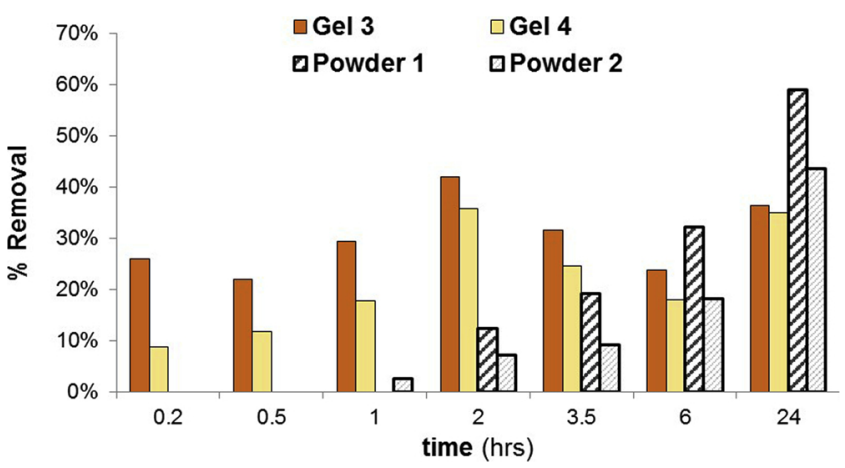

Fig. 2. Comparison of As adsorption using FeEPS in gel and powder (more details in Annex A4).

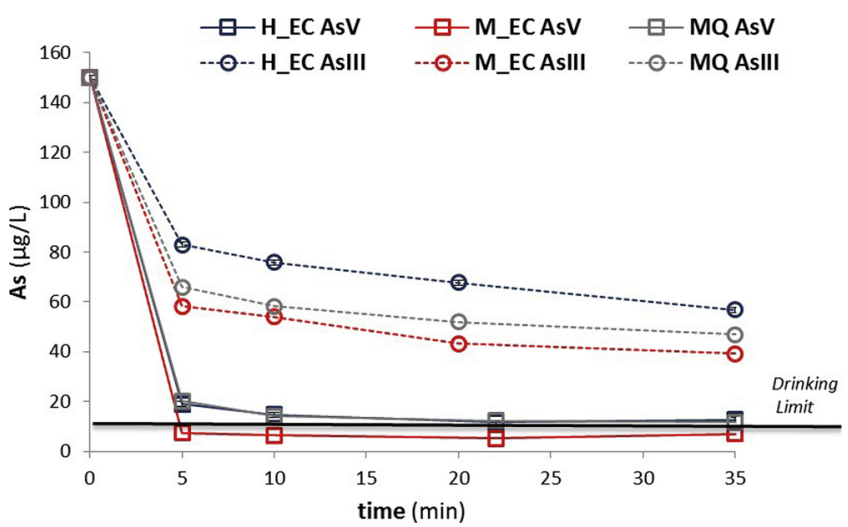

Fig. 3. Fast adsorption in real matrices at different ionic strengths at $150 \mu \mathrm{g} / \mathrm{L}$ initial As concentration. Drinking water limit at $10 \mu \mathrm{g} / \mathrm{L}$ is reported as straight black line.

\subsection{Adsorption and desorption processes}

Isotherm adsorption tests were carried out in the range $0.25-20 \mathrm{mg} /$ L using 10\% FeEPS for both As(V) and As(III) and 5\% FeEPS powder only for $\mathrm{As}(\mathrm{V})$. Elaborated isotherms showed very different shapes with higher adsorption for $\mathrm{As}(\mathrm{V})$ (Fig. 4). On the contrary, higher initial As concentrations increased arsenite adsorption due to facilitated intraparticle diffusion of this neutral specie within the mesoporous FeEPS structure.

Isotherm models summary is reported in Table 2 and fits in Annex
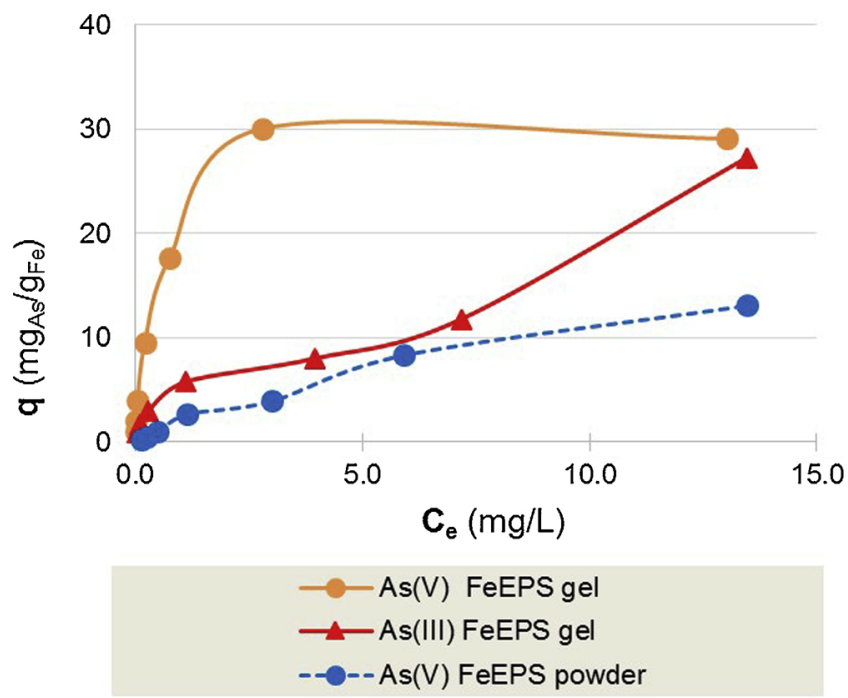

Fig. 4. Arsenic adsorption isotherms as function of As speciation and adsorbent material Adsorption isotherm on powder showed lower As(V) removal capacity compared to hydrogel.

A5. Langmuir isotherm best fit $\mathrm{As}(\mathrm{V})$ adsorption in both gel and powder. Equilibrium maximum adsorption capacity $\left(\mathrm{q}_{\max }\right)$ was $31.8 \mathrm{mg}_{\mathrm{As}} / \mathrm{g}_{\mathrm{Fe}}$, for FeEPS gel while $26.8 \mathrm{mg}_{\mathrm{As}} / \mathrm{g}_{\mathrm{Fe}}$ for FeEPS powder. Arsenite adsorption showed a typical multilayer adsorption, as confirmed by best fit of BET model to this dataset, with $1^{\text {st }}$ layer adsorption capacity of $8.0 \mathrm{mg}_{\mathrm{As}} / \mathrm{g}_{\mathrm{Fe}}$. FeEPS adsorption capacities replicate average iron oxy-hydroxide capacity of $20-60 \mathrm{mg}_{\mathrm{As}} / \mathrm{g}_{\mathrm{Fe}}$ usually reported in literature $[1,41,54]$.

Adsorption capacity of $10 \%$ FeEPS gel after consecutive exposures to $150 \mu \mathrm{g} / \mathrm{L}$ of both $\mathrm{As}(\mathrm{V})$ and $\mathrm{As}(\mathrm{III})$ was tested after $30 \mathrm{~min}$ contact time (see Section 2.4.1). After $1^{\text {st }}$ adsorption $\mathrm{As}(\mathrm{V})$ removal was above $90 \%$ and As(III) above $50 \%$ in all water matrices. After $3^{\text {rd }}$ adsorption run, arsenate removal decreased to $56-66 \%$ and arsenite to $25-37 \%$. The amount of As adsorbed after all three consecutive adsorption was $1.45-1.61 \mathrm{mg}_{\mathrm{As}} / \mathrm{g}_{\mathrm{Fe}}$ for $\mathrm{As}(\mathrm{V})$ and $0.78-1.08 \mathrm{mg}_{\mathrm{As}} / \mathrm{g}_{\mathrm{Fe}}$ for As(II) with in both cases higher amount for M_EC water (see Table 3). If we consider that Fe milliequivalents in solution were 3 order of magnitude higher than those of As, the observed adsorption capacity decrease of FeEPS gel, about $30-40 \%$ for both species and in all matrices, could not be attributed to lack of adsorption sites but to As species reduced access. This aspect should be carefully evaluated for FeEPS gel application and 
Table 2

Isotherms models applied to As(V) and (III) removal in both gel and powder FeEPS material. Parameters characteristics of each model are reported together with $\mathrm{R}^{2}$ and RMSE to evaluate the goodness of model fit.

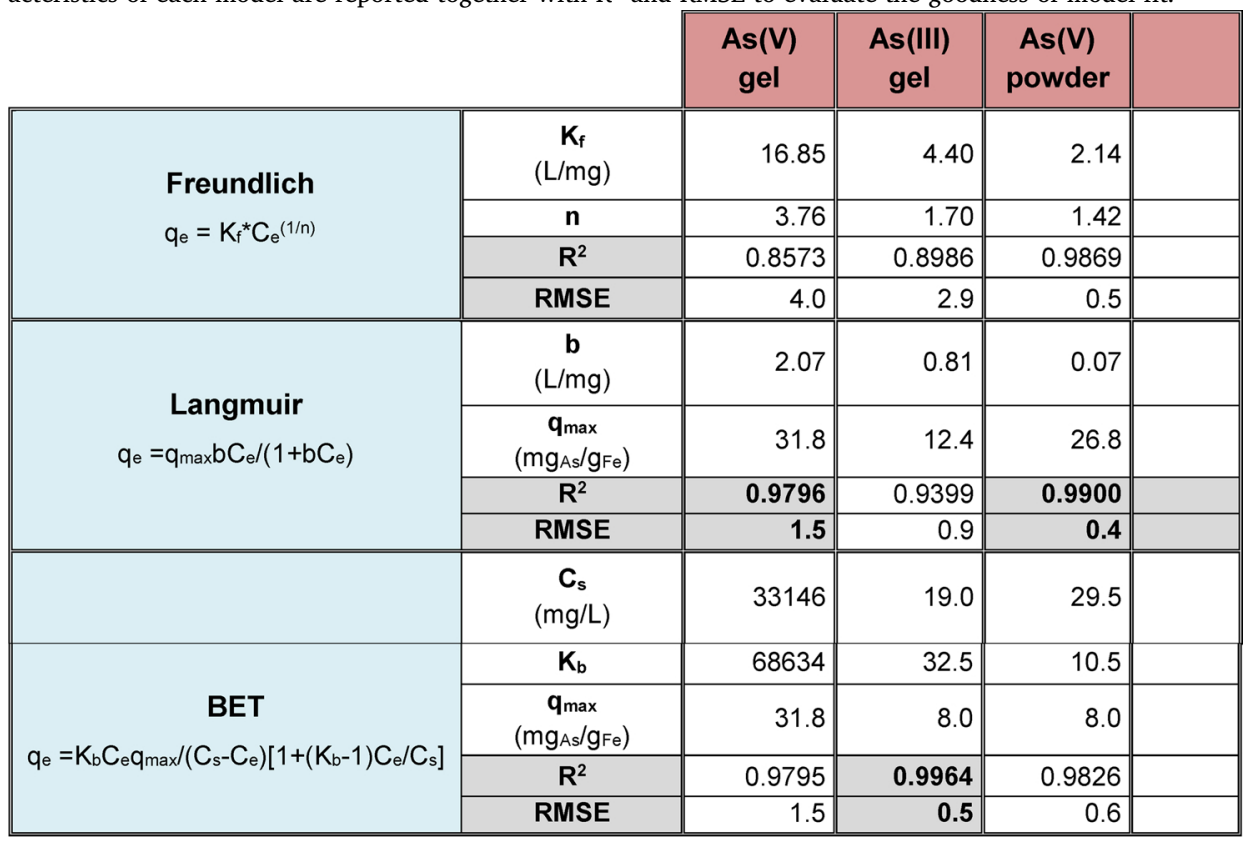

Table 3

Columns with reddish headings report removal efficiencies in 3 water matrices for both $\mathrm{As}(\mathrm{V})$ and $\mathrm{As}(\mathrm{III})$ in the case of consecutive adsorptions. In blueish headings, columns refer to \% of As desorbed after 16 hs and 3 days contact time with MilliQ. Grey cells refer to As(V) and white cells to As(III). Arsenic desorption was calculated according to following expression: [As released in solution (mg)]/[Cumulative amount of As adsorbed (Ads ${ }_{1}+\mathrm{Ads}_{2}+\mathrm{Ads}_{3}$ ) in mg].

\begin{tabular}{|c|c|c|c|c|c|c|}
\hline & $\mathbf{A d s}_{1}$ & $\mathbf{A d s}_{2}$ & $\mathbf{A d s}_{3}$ & $\begin{array}{l}\text { TOT Ads } \\
\mathrm{mg}_{\mathrm{As}} / \mathrm{g}_{\mathrm{Fe}}\end{array}$ & $\begin{array}{c}\text { Des } \\
16 \mathrm{hrs}\end{array}$ & $\begin{array}{c}\text { Des } \\
3 \text { days }\end{array}$ \\
\hline $\begin{array}{l}\mathrm{MQ} \\
\mathrm{AsV}\end{array}$ & $92 \%$ & $67 \%$ & $60 \%$ & 1.45 & $12 \%$ & $7 \%$ \\
\hline $\begin{array}{c}M Q \\
\text { AsIII }\end{array}$ & $69 \%$ & $43 \%$ & $37 \%$ & 0.99 & $5 \%$ & $1 \%$ \\
\hline M_EC & $95 \%$ & $82 \%$ & $66 \%$ & 1.61 & $4 \%$ & $2 \%$ \\
\hline M_EC & $74 \%$ & $53 \%$ & $35 \%$ & 1.07 & $9 \%$ & $3 \%$ \\
\hline $\begin{array}{c}\mathrm{H}_{-} \mathrm{EC} \\
\text { AsV }\end{array}$ & $92 \%$ & $76 \%$ & $56 \%$ & 1.49 & $7 \%$ & $6 \%$ \\
\hline $\begin{array}{c}\text { H_EC } \\
\text { AsIII }\end{array}$ & $55 \%$ & $38 \%$ & $25 \%$ & 0.78 & $12 \%$ & $4 \%$ \\
\hline
\end{tabular}

potentialities. Low $\mathrm{pH}_{\mathrm{pzc}}$ of FeEPS, unfavourable for oxyanions adsorption, and the possible simultaneous role of complexing molecules present in the EPS gel, could promote desorption phenomena when Asfree solution is in contact with the adsorbent. Desorption test showed low As release in solution, corresponding to $5-12 \%$ after 16 hs and 1-7 $\%$ after 3 days, with no large differences among As(V) and As(III) and evidences of re-equilibration of adsorption in the long run.

\subsection{FeEPS efficiency under continuous removal}

A preliminary column study was carried out to evaluate FeEPS efficiency once immobilized on a solid support (bivalve shell debris) and under continuous regime. A small column containing only $4 \mathrm{~g}$ of adsorbent $(40 \mathrm{mg} \mathrm{Fe})$ was fed at $10 \mathrm{ml} / \mathrm{min}$. Before reaching complete breakthrough $\left(\mathrm{C}_{0} / \mathrm{C}_{\mathrm{i}}\right.$ close to 1$)$, column treated about $25 \mathrm{~L}$ of $\mathrm{H}-\mathrm{EC}$ water, corresponding to approximately 8000 BVs. Arsenic removal quickly decreased to $50 \%$ (Fig. 5) and outflow As concentration was

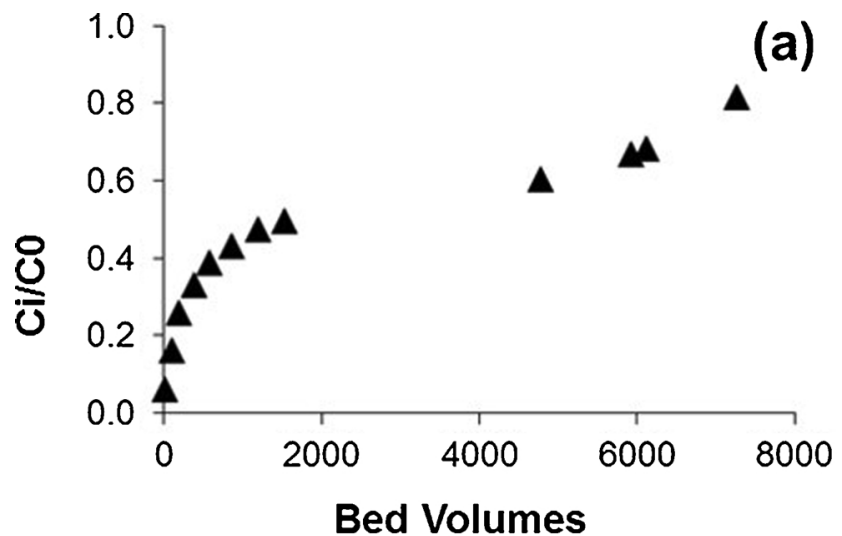

(b)

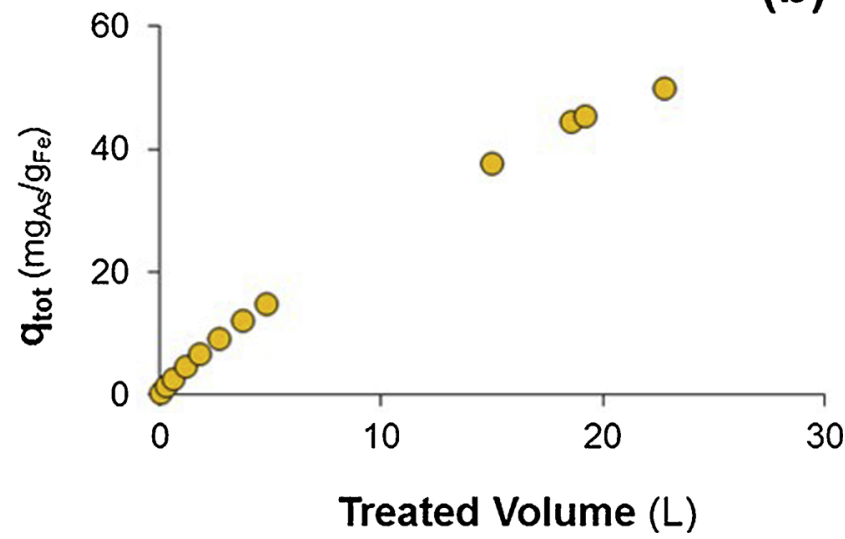

Fig. 5. Arsenic removal capacity in packed-bed fed by $200 \mu \mathrm{g} / \mathrm{L}$ As(V) spiked groundwater (H-EC) at $10 \mathrm{ml} / \mathrm{min}$.

always above the drinking limit of $10 \mu \mathrm{g} / \mathrm{L}$, but this was expected due to the reduced dimension of the used packed-bed. On the other side, the final amount of As adsorbed onto Fe present was $49.8 \mathrm{mg}_{\mathrm{As}} / \mathrm{g}_{\mathrm{Fe}}$, indicating good performance of the FeEPS solid material that it could 
surely represent a promising way of using Fe biogenerated NPs in adsorption filters. Iron in the outflow was always absent, indicating lack of FeEPS detachment from support. Long-term pilot scale studies based on larger volume filters are advisable to understand the real potentialities of this material to treat As-rich groundwater for the production on drinking water.

\section{Conclusions}

The growing interest in water treatment to find environmentally safe technologies for water and soil remediation motivates interest towards biologically based technological approaches. Recently biosorption through microbial biomass and their products is one of the most studied [30]. At the same time the amazing efficiency of NPs also valued nano-sized materials application in this sector, especially Fe oxyhydroxides [55]. The implementation of advanced nanotechnology to traditional water and wastewater technology processes treatments offers new opportunities in these fields [3]. The combination of bacterialdriven synthesis with nanotechnology, it is now widely explored due to the reduced environmental impact of new biogenerated materials, elevated efficiency and their reduced costs. For instance, commercially nano-sized magnetite $(25-50 \mathrm{~nm})$ may cost $\$ 500 / \mathrm{kg}$ while microbial processes are potentially capable of producing $5-90 \mathrm{~nm}$ pure or substituted magnetites at a fraction of the cost of traditional chemical synthesis (Moon et al., 2010). In the last decades, arsenic nano- and bioremediation has received significant attention due to its cost effectiveness and environmental compatibility [56-58].

Our results showed that biologically produced FeEPS gel has good potentialities as "green" material to remove As from contaminated waters (drinking and waste waters) with possible application for soil remediation, as well. Fast kinetic, good adsorption capacity (both as hydrogel or deposited onto solid) and efficiency in real groundwater render this material suitable for As-rich groundwater treatment. Processes involved in the adsorption and the specific role of Fe NPs and EPS matrix in As removal should be further investigated. EPS could be improved by functionalization/doping it to reduce negative surface charges. A protocol to improve its adsorption/embedding into porous solid structure is also required to implement the use of this materials for the removal of oxyanions (As, Cr, V, Se) removal in a continuous fixed bed reactor on a long term basis.

Main findings were:

- FeEPS hydrogel have $\mathrm{pH}_{\mathrm{pzc}}$ corresponding to 3.2, hence less favourable to arsenic adsorption than $\mathrm{Fe}$ oxy-hydroxides nanoparticles;

- Arsenic adsorption was very fast and follows pseudo- $2^{\text {nd }}$ order kinetic with maximum adsorption capacity reached at about $30 \mathrm{~min}$. Higher removal efficiency were recorded for more concentrated FeEPS solution due to higher amount of Fe-nanoparticles present, but specific adsorption capacity increased with solution dilution. Intraparticle diffusion within the pores appears the only involved and rate-limiting process suggesting that ionic repulsion could be balanced by other processes, i.e. chelation by EPS, that favours fast film diffusion. Treatment of natural As levels in mimicked groundwaters showed $87-95 \% \mathrm{As}(\mathrm{V})$ and $45-61 \% \mathrm{As}(\mathrm{III})$ removal after $5 \mathrm{~min}$;

- Dehydrated FeEPS gel showed around 50\% As removal on a long run but it is not suitable for drinking water application due to the extremely slow adsorption kinetics;

- Adsorption followed Langmuir process for As(V) and BET model with increased adsorption at higher initial As concentration for As (III). In FeEPS $10 \%$ solution $\mathrm{q}_{\max }$ was $31.8 \mathrm{mg}_{\mathrm{As}} / \mathrm{g}_{\mathrm{Fe}}$ for As(V) while first layer As(III) adsorption was $8 \mathrm{mg}_{\mathrm{As}} / \mathrm{g}_{\mathrm{Fe}}$ with a $30 \%$ adsorption reduction after three consecutive adsorption for both As species;

- Desorption was below $10 \%$ hence As re-mobilization was limited;

- Immobilization of FeEPS onto carbonaceous shells was successful to obtain good filtering material able to adsorb $49.8 \mathrm{mg}_{\mathrm{As}} / \mathrm{g}_{\mathrm{Fe}}$ at initial $\mathrm{As}(\mathrm{V})$ concentration of $150 \mu \mathrm{g} / \mathrm{L}$ before reaching breakthrough at 8000 BVs.

\section{Acknowledgement}

Authors acknowledge the financial support by Italian MIUR PRIN 2010-2011 project (Grant agreement No 2010JBNLJ7-002).

\section{Appendix A. Supplementary data}

Supplementary material related to this article can be found, in the online version, at doi:https://doi.org/10.1016/j.jece.2019.102908.

\section{References}

[1] D. Mohan, C.U. Pittman, Arsenic removal from water/wastewater using adsorbentsa critical review, J. Hazard. Mater. 142 (2007) 1-53, https://doi.org/10.1016/j. jhazmat.2007.01.006.

[2] S. Bhattacharya, I. Saha, A. Mukhopadhyay, D. Chattopadhyay, U. Chand, ISSN 2249-8532 Original Article Role of nanotechnology in water treatment and purification: potential applications and implications, 3 (2013) 59-64.

[3] I. Gehrke, A. Geiser, A. Somborn-Schulz, Innovations in nanotechnology for water treatment, Nanotechnol. Sci. Appl. 8 (2015) 1-17, https://doi.org/10.2147/NSA S43773.

[4] P. Westerhoff, P. Alvarez, Q. Li, J. Gardea-Torresdey, J. Zimmerman, Overcoming implementation barriers for nanotechnology in drinking water treatment, Environ. Sci. Nano 3 (2016) 1241-1253, https://doi.org/10.1039/C6EN00183A.

[5] E. Deliyanni, D.N. Bakoyannakis, I. Zouboulis, K. Matis, Sorption of As (V) ions by akaganeite-type nanocrystals, 50 (2003) 155-163.

[6] E. Deliyanni, L. Nalbandian, K. Matis, Adsorptive removal of arsenites by a nanocrystalline hybrid surfactant-akaganeite sorbent, J. Colloid Interface Sci. 302 (2006) 458-466, https://doi.org/10.1016/j.jcis.2006.07.007.

[7] Y.X. Zhang, Y. Jia, A facile solution approach for the synthesis of akaganéite ( $\beta$ $\mathrm{FeOOH}$ ) nanorods and their ion-exchange mechanism toward As(V) ions, Appl. Surf. Sci. 290 (2014) 102-106, https://doi.org/10.1016/j.apsusc. 2013.11.007.

[8] X. Sun, C. Hu, X. Hu, J. Qu, M. Yang, Characterization and adsorption performance of Zr-doped akaganéite for efficient arsenic removal, J. Chem. Technol. Biotechnol. 88 (2013) 629-635, https://doi.org/10.1002/jctb.3878.

[9] T. Tuutijärvi, J. Lu, M. Sillanpää, G. Chen, As(V) adsorption on maghemite nanoparticles, J. Hazard. Mater. 166 (2009) 1415-1420, https://doi.org/10.1016/j. jhazmat.2008.12.069.

[10] S.R. Chowdhury, E.K. Yanful, A.R. Pratt, Arsenic removal from aqueous solutions by mixed magnetite-maghemite nanoparticles, Environ. Earth Sci. 64 (2011) 411-423, https://doi.org/10.1007/s12665-010-0865-z.

[11] M. Auffan, J. Rose, O. Proux, D. Borschneck, A. Masion, P. Chaurand, J.L. Hazemann, C. Chaneac, J.P. Jolivet, M.R. Wiesner, A. Van Geen, J.Y. Bottero, Enhanced adsorption of arsenic onto maghemites nanoparticles: As(III) as a probe of the surface structure and heterogeneity, Langmuir. 24 (2008) 3215-3222, https://doi.org/10.1021/la702998x.

[12] J.T. Mayo, C. Yavuz, S. Yean, L. Cong, H. Shipley, W. Yu, J. Falkner, A. Kan, M. Tomson, V.L. Colvin, The effect of nanocrystalline magnetite size on arsenic removal, Sci. Technol. Adv. Mater. 8 (2007) 71-75, https://doi.org/10.1016/j. stam.2006.10.005.

[13] Z. Bujňáková, P. Baláž, A. Zorkovská, M.J. Sayagués, J. Kováč, M. Timko, Arsenic sorption by nanocrystalline magnetite: an example of environmentally promising interface with geosphere, J. Hazard. Mater. 262 (2013) 1204-1212, https://doi. org/10.1016/j.jhazmat.2013.03.007.

[14] C.T. Yavuz, J.T. Mayo, C. Suchecki, J. Wang, A.Z. Ellsworth, H. D'Couto, E. Quevedo, A. Prakash, L. Gonzalez, C. Nguyen, C. Kelty, V.L. Colvin, Pollution magnet: nano-magnetite for arsenic removal from drinking water, Environ. Geochem. Health 32 (2010) 327-334, https://doi.org/10.1007/s10653-0109293-y.

[15] M.K. Ghosh, G.E.J. Poinern, T.B. Issa, P. Singh, Arsenic adsorption on goethite nanoparticles produced through hydrazine sulfate assisted synthesis method, Korean J. Chem. Eng. 29 (2012) 95-102, https://doi.org/10.1007/s11814-0110137-y.

[16] D.N. Bakoyannakis, E. Deliyanni, I. Zouboulis, K. Matis, L. Nalbandian, T. Kehagias, Akaganeite and goethite-type nanocrystals: synthesis and characterization, Microporous Mesoporous Mater. 59 (2003) 35-42, https://doi.org/10.1016/S1387. 1811(03)00274-9.

[17] K. Gupta, T. Basu, U.C. Ghosh, Sorption characteristics of arsenic (V) for removal from water using agglomerated nanostructure Iron (III) -Zirconium (IV) bimetal mixed oxide, Engineering (2009) 2222-2228.

[18] K. Gupta, K. Biswas, U.C. Ghosh, Nanostructure Iron (III) - zirconium (IV) binary mixed oxide : synthesis, characterization, and physicochemical aspects of arsenic (III) sorption from the Aqueous Solution, Ind. Eng. Chem. Res. (2008) 9903-9912, https://doi.org/10.1021/ie8002107.

[19] K. Gupta, U.C. Ghosh, Arsenic removal using hydrous nanostructure iron(III)-titanium(IV) binary mixed oxide from aqueous solution, J. Hazard. Mater. 161 (2009) 884-892, https://doi.org/10.1016/j.jhazmat.2008.04.034. 
[20] L. Chen, H. Xin, Y. Fang, C. Zhang, F. Zhang, X. Cao, X. Li, Application of metal oxide heterostructures in arsenic removal from contaminated water, J. Nanomater. (2014) 1-10 http://www.hindawi.com/journals/jnm/2014/793610/.

[21] Z. Ren, G. Zhang, J. Paul Chen, Adsorptive removal of arsenic from water by an iron-zirconium binary oxide adsorbent, J. Colloid Interface Sci. 358 (2011) 230-237, https://doi.org/10.1016/j.jcis.2011.01.013.

[22] Y.M. Zheng, S.F. Lim, J.P. Chen, Preparation and characterization of zirconiumbased magnetic sorbent for arsenate removal, J. Colloid Interface Sci. 338 (2009) 22-29, https://doi.org/10.1016/j.jcis.2009.06.021.

[23] S. Iravani, Bacteria in Nanoparticle Synthesis: Current Status and Future Prospects, Int. Sch. Res. Not. 2014 (2014) 1-18, https://doi.org/10.1155/2014/359316.

[24] S. Saif, A. Tahir, Y. Chen, Green synthesis of Iron nanoparticles and their environmental applications and implications, Nanomaterials 6 (2016) 209, https:// doi.org/10.3390/nano6110209.

[25] K.Revati Abhilash, B.D. Pandey, Microbial synthesis of iron-based nanomaterials-a review, Bull. Mater. Sci. 34 (2011) 191-198, https://doi.org/10.1007/s12034-0110076-6.

[26] D.R. Lovley, Magnetite formation during microbial dissimilatory iron reduction, Iron Biominer. Springer US, Boston, MA, 1991, pp. 151-166, https://doi.org/10. 1007/978-1-4615-3810-3 11.

[27] F. Baldi, A. Minacci, M. Pepi, A. Scozzafava, Gel sequestration of heavy metals by Klebsiella oxytoca isolated from iron mat, FEMS Microbiol. Ecol. 36 (2001) 169-174 (accessed March 1, 2017), http://www.ncbi.nlm.nih.gov/pubmed/ 11451521.

[28] S. Leone, C. De Castro, M. Parrilli, F. Baldi, R. Lanzetta, Structure of the ironbinding exopolysaccharide produced anaerobically by the gram-negative BacteriumKlebsiella oxytoca BAS-10, Eur. J. Org. Chem. 2007 (2007) 5183-5189, https://doi.org/10.1002/ejoc.200700302.

[29] F. Baldi, D. Marchetto, D. Battistel, S. Daniele, C. Faleri, C. De Castro, R. Lanzetta, Iron-binding characterization and polysaccharide production by Klebsiella oxytoca strain isolated from mine acid drainage, J. Appl. Microbiol. 107 (2009) 1241-1250, https://doi.org/10.1111/j.1365-2672.2009.04302.x.

[30] P. Gupta, B. Diwan, Bacterial Exopolysaccharide mediated heavy metal removal: a Review on biosynthesis, mechanism and remediation strategies, Biotechnol. Rep. Amst. (Amst) 13 (2017) 58-71, https://doi.org/10.1016/J.BTRE.2016.12.006.

[31] S. Comte, G. Guibaud, M. Baudu, Biosorption properties of extracellular polymeric substances (EPS) towards $\mathrm{Cd}, \mathrm{Cu}$ and $\mathrm{Pb}$ for different $\mathrm{pH}$ values, J. Hazard. Mater. 151 (2008) 185-193, https://doi.org/10.1016/J.JHAZMAT.2007.05.070.

[32] F. Baldi, D. Marchetto, D. Zanchettin, E. Sartorato, S. Paganelli, O. Piccolo, A biogenerated Fe(III)-binding exopolysaccharide used as new catalyst for phenol hydroxylation, Green Chem. 12 (2010) 1405, https://doi.org/10.1039/c004967k

[33] I. Arčon, O. Piccolo, S. Paganelli, F. Baldi, XAS analysis of a nanostructured iron polysaccharide produced anaerobically by a strain of Klebsiella oxytoca, BioMetals 25 (2012) 875-881, https://doi.org/10.1007/s10534-012-9554-6.

[34] B. Casentini, F.T. Falcione, S. Amalfitano, S. Fazi, S. Rossetti, Arsenic removal by discontinuous ZVI two steps system for drinking water production at household scale, Water Res. 106 (2016) 135-145, https://doi.org/10.1016/j.watres.2016.09. 057.

[35] S. Fazi, S. Crognale, B. Casentini, S. Amalfitano, F. Lotti, S. Rossetti, The arsenite oxidation potential of native microbial communities from arsenic-rich freshwaters, Microb. Ecol. 72 (2016), https://doi.org/10.1007/s00248-016-0768-y.

[36] M. Rotiroti, E. Sacchi, L. Fumagalli, T. Bonomi, Origin of arsenic in groundwater from the multilayer aquifer in Cremona (Northern Italy), Environ. Sci. Technol. 48 (2014) 5395-5403, https://doi.org/10.1021/es405805v.

[37] Y.S. Ho, G. McKay, A comparison of chemisorption kinetic models applied to pollutant removal on various sorbents, Process Saf. Environ. Prot. 76 (1998) 332-340, https://doi.org/10.1205/095758298529696.

[38] Y.S. Ho, Review of second-order models for adsorption systems, J. Hazard. Mater. 136 (2006) 681-689, https://doi.org/10.1016/j.jhazmat.2005.12.043.

[39] Z.Ö. Kocabaş, Y. Yürüm, Kinetic modeling of arsenic removal from water by ferric ion loaded red mud, Sep. Sci. Technol. 46 (2011) 2380-2390, https://doi.org/10. 1080/01496395.2011.595757.

[40] Y.N. Chen, L.Y. Chai, Y. De Shu, Study of arsenic(V) adsorption on bone char from aqueous solution, J. Hazard. Mater. 160 (2008) 168-172, https://doi.org/10.1016/ j.jhazmat.2008.02.120.

[41] M.C.S. Faria, R.S. Rosemberg, Ca. Bomfeti, D.S. Monteiro, F. Barbosa, L.C. a Oliveira, M. Rodriguez, M.C. Pereira, J.L. Rodrigues, Arsenic removal from contaminated water by ultrafine $\delta$-FeOOH adsorbents, Chem. Eng. J. 237 (2014) 47-54, https://doi.org/10.1016/j.cej.2013.10.006.

[42] H. Qiu, L. Lv, B. Pan, Q.Q. Zhang, W. Zhang, Q.Q. Zhang, Critical review in adsorption kinetic models, J. Zhejiang Univ. Sci. A. 10 (2009) 716-724, https://doi. org/10.1631/jzus.A0820524.

[43] J.-P. Simonin, On the comparison of pseudo-first order and pseudo-second order rate laws in the modeling of adsorption kinetics, Chem. Eng. J. 300 (2016) 254-263, https://doi.org/10.1016/J.CEJ.2016.04.079.

[44] B.I. Olu-Owolabi, P.N. Diagboya, K.O. Adebowale, Evaluation of pyrene sorptiondesorption on tropical soils, J. Environ. Manage. 137 (2014) 1-9, https://doi.org/ 10.1016/j.jenvman.2014.01.048.

[45] K.Y. Foo, B.H. Hameed, Insights into the modeling of adsorption isotherm systems, Chem. Eng. J. 156 (2010) 2-10, https://doi.org/10.1016/j.cej.2009.09.013.

[46] G. Limousin, J.-P. Gaudet, L. Charlet, S. Szenknect, V. Barthès, M. Krimissa, Sorption isotherms: a review on physical bases, modeling and measurement, Appl. Geochem. 22 (2007) 249-275, https://doi.org/10.1016/J.APGEOCHEM.2006.09. 010.

[47] S. Brunauer, P.H. Emmett, E. Teller, Adsorption of gases in multimolecular layers, J. Am. Chem. Soc. 60 (1938) 309-319, https://doi.org/10.1021/ja01269a023.

[48] J.-P. Simonin, On the comparison of pseudo-first order and pseudo-second order rate laws in the modeling of adsorption kinetics, Chem. Eng. J. 300 (2016) 254-263, https://doi.org/10.1016/J.CEJ.2016.04.079.

[49] R.M. Cornell, U. Schwertmann, The Iron Oxides: Structure, Properties, Reactions, Occurrences and Uses, 2nd ed., (2003) Weinheim.

[50] F. Baldi, M. Gallo, S. Daniele, D. Battistel, C. Faleri, A. Kodre, I. Arčon, An extracellular polymeric substance quickly chelates mercury(II) with $\mathrm{N}$-heterocyclic groups, Chemosphere 176 (2017) 296-304, https://doi.org/10.1016/j. chemosphere.2017.02.093.

[51] A. Jain, R.H. Loeppert, Effect of competing anions on the adsorption of arsenate and arsenite by ferrihydrite, J. Environ. Qual. 29 (2000) 1422, https://doi.org/10. 2134/jeq2000.00472425002900050008x.

[52] S. Dixit, J. Hering, Comparison of arsenic (V) and arsenic (III) sorption onto iron oxide minerals: implications for arsenic mobility, Environ. Sci. Technol. 37 (2003) 4182-4189, https://doi.org/10.1021/es030309t.

[53] Y. Arai, D.L. Sparks, J. Davis, Effects of dissolved carbonate on arsenate adsorption and surface speciation at the hematite-water interface, Environ. Sci. Technol. 38 (2004) 817-824, https://doi.org/10.1021/es034800w.

[54] W. Chen, R. Parette, J. Zou, F.S. Cannon, B.A. Dempsey, Arsenic removal by ironmodified activated carbon, Water Res. 41 (2007) 1851-1858, https://doi.org/10. 1016/J.WATRES.2007.01.052.

[55] M. Mohapatra, S. Anand, Synthesis and applications of nano-structured iron oxides/ hydroxides - a review, Int. Res. J. Eng. Sci. Technol. Innov. 2 (2011) 127-146, https://doi.org/10.4314/ijest.v2i8.63846.

[56] S. Fazi, S. Amalfitano, B. Casentini, D. Davolos, B. Pietrangeli, S. Crognale, F. Lotti, S. Rossetti, Arsenic removal from naturally contaminated waters: a review of methods combining chemical and biological treatments, Rend. Lincei. 27 (2016), https://doi.org/10.1007/s12210-015-0461-y.

[57] M.M. Bahar, M. Megharaj, R. Naidu, Bioremediation of arsenic-contaminated water: recent advances and future prospects, Water Air Soil Pollut. 224 (2013) 1722, https://doi.org/10.1007/s11270-013-1722-y.

[58] S. Lata, S.R. Samadder, Removal of arsenic from water using nano adsorbents and challenges: A review, J. Environ. Manage. 166 (2016) 387-406, https://doi.org/10 1016/j.jenvman.2015.10.039. 